\title{
DESCRIPTIVE NOTES OF SOUTHERN HAWKE'S BAY AND NORTHERN WAIRARAPA
}

\author{
J. A. H. INGLIS \\ "Ratahiwi", Woodville
}

THIs is a description of farming in the area of the Manawatu catchment upstream of the Manawatu gorge plus the catchments of the Akitio and Owahanga rivers. This area corresponds closely with the counties of Dannevirke (including Akitio), Woodville, Pahiatua and Eketahuna. The statistics given are for the total of these counties. Without attempting to study the financial implications, some effort is made to pinpoint weaknesses in present farming practices and possibilities for improvement.

The main landscape units within this area are the Tararua and Ruahine ranges and foothills which form the western boundary, a central depression known by geologists as the "Dannevirke-Pahiatua Depression", along which flow the Mangahao, Mangatainoka and upper reaches of the Manawatu, and the eastern hill country which stretches to the Pacific Ocean. The length from north-north-east to south-south-west along the central depression (corresponding to State Highway 2 and the WairarapaHawke's Bay railway line) is about $90 \mathrm{~km}$, and distance along the eastern coast is about $50 \mathrm{~km}$.

\section{LI M A T E}

The climate is characterized by strong north-westerly winds and a well-spread rainfall, mostly within the range of 1000 to $1500 \mathrm{~mm}$ annually, although rainfalls up to $20 \mathrm{Q} 0 \mathrm{~mm}$ occur along the western hill-country fringe. Dry spells are usually of very short duration along the western, hills, but can be quite appreciable, frequently with little rainfall over January to March in the e a s t and north-e as t.

$$
S \quad 0 \quad I \quad L \quad S
$$

In the west, a narrow band of steep hill country between the crest of the divide and the central depression is seldom over $5 \mathrm{~km}$ wide. Forest has been cleared from most of the land suitable for farming. The soils of the farmed land are yellow-brown. earths and related steepland soils, mainly 'well structured, well drained and strongly leached of plant nutrients.

The central depression is about $12 \mathrm{~km}$ wide, consisting of flats, some of which are very recent, some older and with poor drainage, terraces with usually well-drained, friable soils of the 
yellow-brown loam group, and rolling hills with yellow-brown earths and intergrades between these and yellow-grey earths.

The eastern hill country, up to $40 \mathrm{~km}$ wide, consists of rolling to very steep land with small areas of good quality flats. Soils vary greatly from a limited amount of light textured yellowbrown earths (derived from sandstone) to much heavier textured yellow-grey earths, according to the rainfall and the soil parent materials. These' parent materials include sandstones, siltstones, mudstones, limestones, argillite and greywacke, occurring as narrow bands almost parallel to the coastline and the trend of the central depression. Nearly all the eastern hill area is farmed, with a limited amount of the highest ranges remaining in bush.

\section{SETTLEMENT}

All the western hills and the central depression were originally in very heavy forest, the "Seventy-Mile Bush". Further east the cover was mainly forest, though clearings did occur, often vegetated by manuka and fern.

The greater part of the area was initially occupied as "small farm settlements" where people of very limited means were able to take up small bush sections and, usually with a struggle, make them into grass farms. This was probably the only reasonable way the land could have been brought into production. The fact that most of the enormous reserves of good native timber were wasted is perhaps irrelevant, as, without a farming industry, it is unlikely that any use would have been made of the land or its products until a very much later date. Many of the farms were only large enough to become "smallholdings", and until quite recent times it was usual for a number of farmers to work, part time, off their farms. Consolidation has now reached a stage where the marginal-sized farm is uncommon and, of course, in the process a great drop in rural population has occurred. It is also likely that the living standards of those still on the land are higher because of this.

\section{LAND USE}

Statistics as at June 30, 1974, are as follows: Occupied area: 381800 ha in 1601 holdings
Breeding ewes
1571000

Other sheep

652000

Total sheep

2223000 (approx. 1996000 stock units - s.u.) 
$\begin{array}{lll}\text { Beef cows/heifers } 2 \mathrm{yr}+ & 81000 \\ \text { Heifers } 2 \mathrm{yr}- & \ldots & 46000\end{array}$

Other $\quad \ldots, \quad \ldots \quad \ldots, \quad \ldots 1000$

Total beef cattle .... 218000 (approx. 1034000 s.u.)

Dairy cows/heifers

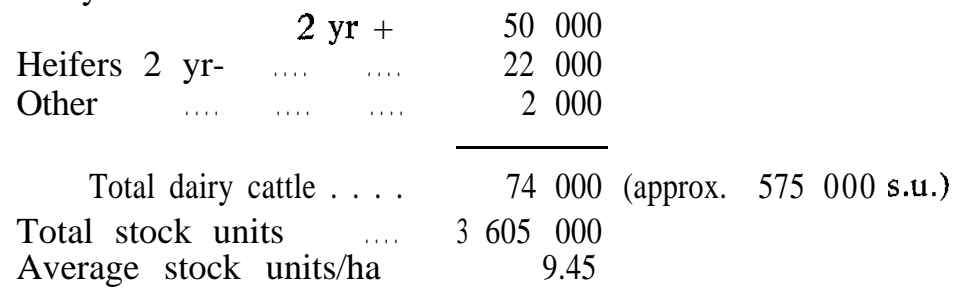

Average stock units/

holding $\quad 2250$

In the central depression and the smaller flats further east, a small but appreciable amount of grain is sown, mostly barley. On the yellow-brown loams there are successful ventures on a substantial scale in potato growing and tree nurseries, some small berryfruit gardens are in the, lower areas, but the climate of high wind-run and frequent precipitation, creates problems in harvesting rather than growing of many crops,

At one time, substantial amounts of brassica crops were grown for fodder. They are now largely replaced by all-grass farming. Some'maize crops are grown for green feed and silage. There are a few cases of dairying under summer irrigation, but the scope for this appears quite limited.

The area probably has a greater proportion of the total in permanent pasture than have most 'districts.

\section{PASTORAL}

Well over half of the total area is, mainly because of contour, only suited to be used as what is known as "breeding country", otherwise defined as "semi-extensive farming". Since the late 1940s, in common with other districts, large increases in sheep and cattle numbers have occurred. Wether lambs used to be mainly sold as stores, whereas now most can be drafted at light weights to the works, with the proviso that as the lamb-fattening farms, particularly those in Central Hawke's Bay, find the supply 
of true store lambs dwindling they are prepared to compete with the exporters for light, killable lambs.

A very substantial number of cast-for-age ewes leave the district each year to areas that are more suited to prime-lamb raising. An appreciable number of cattle are finished on the better areas, but many store cattle move down to the central depression and out of the area.

Stocking of the western fringe could be similarly described except that the area is so narrow that a large proportion of the farms have areas of better land inside the central depression and are therefore more suited to finishing their own stock. The central depression, though much less than half the total area, includes most of the higher-producing land. Along the Manawatu River several farms consist mostly of free-draining recent alluvia and have some flooding risk. They are largely used for cattle fattening. The heavier soils of the flat and easy rolling land are best suited to dairying, the traditional form of farming and still the major one. Dairying is also important on the lighter terraces, especially in the higher rainfall areas. The proportion of land in prime-lamb farming and cattle fattening increases with the lowering of rainfall and/or with the lighter, more loamy soil types.

In a valley such as this, there is no clear line between types of farms, the decision whether to run dairy cows or sheep being probably more dependent on the individual farmer's preference and financial position rather than on whether or not the land is suited to dairying.

\section{PASTURES}

Until 1950, a substantial amount of the hill country was carrying infestations of manuka (Leptospermum scoparium) and/ or gorse (Ulex europaeus), and most pastures on the hills would probably have been carrying. approximately 2 to $21 / 2 \mathrm{~s} . \mathrm{u}$./ha on Agrosfis-dominant swards, although over the greater part of the area better pasture species could be found, mainly in fertile hollows and areas favoured by stock. Aerial topdressing and fencing, together with a considerable amount of cultivation with giant discs, plus scrub felling and spraying for gorse, have brought most of the hill country to at least reasonably good pastures. The pastures on the flat and near-flat land largely have a longer history of phosphate topdressing and liming and have higher fertility on the damper areas. 


\section{FERTILIZERS}

There have never been any notable problems of stock health in the area, but without the use of phospate only a low level of production is possible except on the recent alluvia. The most recent Manawatu-type alluvia near the main streams have $\mathrm{pH}$ levels of 5.6 to 6.3 , not generally requiring liming. The hill soils have a natural pH generally between 5.2 and 5.7 , so that much of the hill area may be expected to benefit from liming. The remaining flats and terraces vary from 5.3 to 6.3 and it is fair to say that nearly all the area can benefit from lime. Work by Roger Ball (unpublished) on Whetukura hill soils (yellow-brown earths) north of Woodville in 1970 suggested that, when phosphate levels are reasonable but $\mathrm{pH}$ is below 5.4, application of $\mathbf{5}$ t/ha of lime could increase winter pasture production by $50 \%$. However, the long-term effects of liming were not assessed.

In most areas, probably an initial build up of phosphate is (or was) required, often with addition of molybdenum, and lime if finances allow.

Potassium levels usually become limiting only after a long period of dairying with attendant haying. Maintenance levels of phosphate, are about 250 to $300 \mathrm{~kg} / \mathrm{ha}$ of superphosphate and potassium is used in addition, along with perhaps more superphosphate on many intensively farmed dairy units.

It would seem that the phosphate and pH levels on much hill country are well below optimum.

Selenium and copper responses from application to animals are claimed in various areas, particularly on hill country.

\section{CURRENT POSITION}

The levels of stocking have been roughly static- for several years, with an apparent movement to more sheep and fewer cattle, and some reduction in the number of dairy herds.

There are considerable problems of insect pests of pasture. Grass grub is very troublesome on the yellow-brown loams and other light soils, probably increasingly so. Porina populations exploded in many areas during the 1960s but seemed to have settled down considerably, probably at least partly from effects of overcrowding, and also from improved grazing management in autumn. Chemical control of grass grub is practised on many flat and near-flat areas, but otherwise farmers have learned to live with the insects. In the higher rainfall areas, poor drainage can lead to gleyed soils and considerable infestation of rushes. 
even on quite steep slopes. Infestations of gorse and manuka are largely controlled and nodding and variegated thistles are not much in evidence. Ragwort is giving cause for concern on lighter dairying land. Much drainage has been carried out and on the flat to easy land much more is required.

\section{FUTURE PROSPECTS}

The pastures on most farms, even the ones regarded as wellfarmed, are still mostly well below optimum quality, with considerable occurrence of browntop and Yorkshire fog, although the general quality of pastures would compare well with those of other districts.

The writer submits that the limiting factors to higher pastoral production are (in probable order of importance) :

(1) Grazing management, which is often well below optimum. Set-stocking is still a common practice on hill country.

(2) Fencing. Not many of the larger holdings have enough paddocks for good rotational grazing management. Cheap electric fencing offers great scope.

(3) Low pH levels, especially on the hills.

(4) Need for more drainage on the flat and easy land.

(5) Low nitrogen availability in winter-spring. The work of Ball et al. (1976) indicates very considerable scope for use of fertilizer nitrogen.

(6) Low levels of phosphorus and molybdenum still occur on hill country, but to a much lesser extent than several years ago.

(7) Shortage of good water for stock. Water is always available for reticulation.

(8) Easier control of insect pests of pasture would be of some help.

The whole area is tied to pastoral production because, even on the flat land, summer-autumn rain makes crop harvesting difficult. Some of the poorer and less stable hills could well be planted in timber. Radiata pine thrives on them. Production of horticultural crops is probably limited to seedling trees and potatoes. The writer hesitates to guess the export potential of the latter.

It is likely that the general application of knowledge already available would increase the pastoral production to $15 \mathrm{s.u} . / \mathrm{ha}$, . but such an increase overnight is not practicable and would re- 
quire a large increase in the labour force, both farming and farm servicing. No doubt subdivision of larger holdings would tend to increase the labour force and production.

An increase from the present 9.5 s.u./ha to 12.5 s.u./ha would give an extra 1.17 million s.u., and at 15 s.u./ha the figure would give almost another million to increase total stocking from 3.6 to 5.7 million. Without attempting to go outside the scope of this paper and predict market prices, it is reasonable to suggest that total production, plus employment in processing within the valley, would increase if there were a swing to more dairying.

\section{ACKNOWLEDGEMENTS}

The writer acknowledges considerable help from J. D. Cowie, Soil Bureau, DSIR, Palmerston North, who supplied material on geology and soils, and the staff of Ministry of Agriculture and Fisheries, Dannevirke, for statistics and comments on soil fertility levels.

\section{REFERENCE}

Ball, R.;. Inglis, J. A. H.; Mauger, J. H., 1976. Proc. N.Z. Grassld Ass., 37 (2): $166-81$. 